\title{
KONSTRUKSI MUTAN PROTEIN FOSFATASE ptc $2 \Delta$ Saccharomyces cerevisiae DENGAN METODE PENGGANTIAN GEN TARGET DENGAN POLYMERASE CHAIN REACTION (PCR)
}

\author{
Hermansyah \\ Jurusan Kimia FMIPA Universitas Sriwijaya
}

\begin{abstract}
Yeast Saccharomyces cerevisiae is an excellent model to studi genes function of eukarotic cells such as study of gene encoding protein phosphatase PTC2. Novel phenotypic caused by mutated gene is an important step to study function of gene. In this study constructed mutant of PTC2 gene encoding protein phosphatase. Method that used in this construction was replacement of target gene (PTC2) with auxotroph marker Candida albicans HIS3 by Polymer Chain Reaction (PCR) or called by PCR-mediated disruption. Mutant colonies which grew in selective medium SC without histidine were confirmed by PCR amplification. By using 1\% Agarose gel electrophoresis the result showed that size of ptc $2 \Delta:: C g H I S 3$ transformant was $3.52 \mathrm{~kb}$ while wild type strain was $2.9 \mathrm{~kb}$, indicated that $p t c 2 \Delta:: C g H I S 3$ has integrated on chromosome $\mathrm{V}$ replacing PTC2 wild type.
\end{abstract}

\section{Keywords: PTC2, Saccharomyces cereviciae, PCR, single disruptant}

\section{PENDAHULUAN}

Ragi Saccaromyces cerevisiae (S. cerevisiae) merupakan mikro organisme eukariyot yang paling banyak dijadikan sebagai model penelitian dalam biologi molekuler. Hal ini karena ragi memiliki berbagai kelebihan diantaranya pertumbuhan ragi cepat, pola 'budding' yang menghasilkan sel tersebar, mudah untuk dilakukan replika plating, sistem genetik ragi telah diketahui dengan baik, dan transformasi DNA ke ragi sangat mudah dilakukan. Mudahnya proses transformasi ragi ini dimanfaatkan oleh para peneliti gen mamalia dengan mentransfer gen mamalia ke ragi untuk analisis sintetik fungsi protein.

S. cerevisiae memiliki 16 kromosom yang telah terkarakterisasi dengan baik dimana masing-masing berukuran 200 hingga $2.200 \mathrm{~kb}$. Total ukuran DNA kromosom ini $12.052 \mathrm{~kb}$. Sebanyak 6.183 open reading frame (ORF) yang dimiliki ragi $S$. cerevisiae, hanya 5.773 gen yang mengkode protein dan mengandung intron $3,8 \%$ nya mengandung intron. Gen-gen ragi rata-rata berukurang $1.45 \mathrm{~kb}$ atau 483 kodon (Sherman, 2002. Fungsi dari gen-gen tersebut walaupun telah 
banyak diketahui, namun penemuan-penemuan fenotip baru dari single disruptant telah mengindikasikan bahwa gen-gen ragi memiliki fungsi yang tidak sederhana, melainkan fungsi yang komplek. Fenotipik yang terlihat dari suatu single disruptant ataupun transforman mengisyaratkan bahwa gen tersebut secara molekuler terlibat dalam proses seluler fenotipik yang bersangkutan.

Pendekatan yang biasa digunakan untuk mempelajari fungsi suatu gen ada dua cara. Cara pertama adalah melalui pengrusakan sebagian atau suatu gen kromosom (disruption) yang menyebabkan aktivitas protein yang dikode oleh gen tersebut hilang. Cara kedua adalah dengan mengoverekpresikan suatu gen sehingga diharapkan ekspresi dan aktivitas proteinnya tinggi (Miyakawa dan Mizunuma, et al., 2007). Pembuatan mutan dengan merusak gen lebih banyak dilakukan oleh para peneliti terutama yang bekerja dengan ragi S.cerevisiae dalam mempelajari fungsi suatu gen. Metode penggunaan Polymerase chain reaction $(P C R)$ untuk merusak gen ( PCR- mediated gene disruption) merupakan metode yang banyak digunakan untuk merusak sebagian atau kesuluruhan suatu gen (Hirasaki, et al., 2008).

Protein fosfatase adalah protein yang memindahkan gugus fosfat dari suatu protein atau enzim. Protein fosfatase ini berlawanan dengan protein kinase yang menempelkan gugus fosfat pada protein. Protein fosfatase dan protein kinase mengendalikan berbagai proses seluler, misalnya pada berbagai signal transduksi. Gen PTC2 mengkode protein fosfatase yang diidentifikasikan sebagai protein serin/treonin fosfatase yang fungsinya masih terus diteliti. Fungsi PTC2 yang telah telah diketahui adalah mendefosforilasi Hog1 pada osmostres yang diinduksi oleh aktivitas kinase; mendefosforilasi Ire1 pada downregulasi respon protein unfolded, mendefosforilasi Cdc28, dan meng-inaktivasi DNA checkpoint (Young et al, 2002; Lorey et al, 2003). Tujuan dari penelitian ini adalah untuk mendapatkan mutan gen PTC2 yang digantikan oleh gen HIS3 dari Candida glabrata. Mutan ptc2::CgHIS3 ini akan digunakan untuk mempelajari fungsi PTC2 lebih lanjut.

\section{METODE PENELITIAN}

\section{Strain dan kondisi kultur yang digunakan}

FY833 dengan $\operatorname{can}^{\mathrm{r}}=$ ura3-52

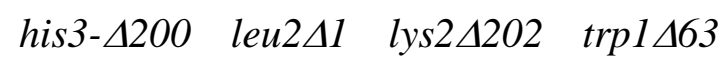
digunakan sebagai wild type strain dan parental strain. Strain ura3-52 his3- 4200 leu2 $21 \quad$ lys $2 \Delta 202 \quad \operatorname{trp} 1 \Delta 63$ ptc2s::CgHIS3.

Medium agar YPDA diperkaya dengan suplemen adenine $0.4 \mathrm{mg} / \mathrm{ml}$ (Sigma- Aldrich Co). Medium selektif terdiri atas yeast nitrogen base tanpa 
amino acids $0,67 \%$, glukosa $2 \%$, bakto agar $2 \%$ dan suplemen-suplemen auksotropi seperti L-triptopan $20 \mathrm{mg} / \mathrm{L}$, L-histidin $(\mathrm{HCl}) \quad 20 \mathrm{mg} / \mathrm{L}, \quad$ L-arginin ( $\mathrm{HCl}) \quad 20 \mathrm{mg} / \mathrm{L}$, L-metionin $20 \mathrm{mg} / \mathrm{L}$, urasil $20 \mathrm{mg} / \mathrm{L}$, L-tirosin $30 \mathrm{mg} / \mathrm{L}$, L-isoleusin $30 \mathrm{mg} / \mathrm{L}$, L-lisin $(\mathrm{HCl}) 30$ $\mathrm{mg} / \mathrm{L}$, L-leusin $100 \mathrm{mg} / \mathrm{L}$, L-valin 150 $\mathrm{mg} / \mathrm{L}$, L-treonin $200 \mathrm{mg} / \mathrm{L}$, dan adenin $400 \mathrm{mg} / \mathrm{L})$.

\section{Polymerase Chain Reaction (PCR)}

Desain pasangan primer untuk PCR yang digunakan untuk konstruksi ptc2 $2 \Delta: \mathrm{Cg} H I S 3$ adalah forward primer (Kf) $\mathrm{Kf}$ (44 to 83)5'ACTCCGGTGC TGACTCCTTG ACCGCGTTTG GACTGTGTGC CACAGGAAAC AGCTATGACC 3' dan $\operatorname{Kr}$ (1155 to 1194) 5'GGGGCCGGAG GTCTTGCTCT TGGATTGGCT GGAAGGGTCA GTTG TAAAAC GACGGCCAGT 3'

Pasangan primer yang digunakan untuk mengkofirmasi terjadinya ppg $1 \Delta:: \mathrm{Cg} H I S 3$ adalah masing-masing terdiri atas 30 nukletida yaitu $\mathrm{Kf}$ : 5' CTC GGATCC

TAAGAAATAT

AACCAATAGC AC 3' dan $\mathrm{Kr}$ : 5' CTC GGATCC TCTTGTCGA G GCTGTCGGAG AA 3'

Campuran reaksi untuk reaksi PCR adalah sebagai berikut: tiap $10 \mu \mathrm{L}$ campuran reaksi terdiri atas $0,1 \mu \mathrm{L}$ Takara Ex Taq ${ }^{\mathrm{TM}}(5$ units/ $\mu \mathrm{L}), 2 \mu \mathrm{L}$ 10x Ex Taq ${ }^{\mathrm{TM}}$ bufer, $2 \mu \mathrm{L}$ campuran dNTP, $0,5 \mu \mathrm{L}$ DNA template $(74 \mathrm{ng} / \mu \mathrm{L}), 1 \mu \mathrm{L}$ forward primer, $1 \mu \mathrm{L}$ reverse primer, 3,4 $\mu \mathrm{l}$ air steril. Kondisi reaksi PCR adalah sebagai berikut: siklus reaksi $25 \mathrm{X}$, denaturasi pada $94^{\circ} \mathrm{C}$ selama 0,5 menit, annealing pada $60^{\circ} \mathrm{C}$ selama 30 detik, ekstensi pada $72^{\circ} \mathrm{C}$ selama 3 menit. Hasil amplifikasi PCR diperiksa dengan gel elektroforesis agarosa $1 \%$.

\section{Transformasi pada ragi}

Transformasi pada ragi menggunakan metode $\mathrm{Li}$ asetat. (Hermansyah, et al., 2009). Sel ragi diinokulasi pada medium YPDA. Pindahkan 0,5 mL kultur sel ke $5 \mathrm{~mL}$ media kultur baru. Inkubasi dengan shaker $150 \mathrm{rpm}$ selama 3 hingga 4 jam hingga meraih $\mathrm{OD}_{660}=1,0$. Sel dipanen dan dikumpulkan dengan sentrifugasi $2.000 \mathrm{rpm}$ selama 5 menit dan dicuci dengan $5 \mathrm{~mL}$ air steril. Sel di larutkan kembali dengan $1 \mathrm{~mL}$ Li.asetat $0,1 \mathrm{M}$ dan pindahkan suspensi sel ke dalam 1,5 mL tube untuk disentrifugasi pada 12.000 rpm selama 30 detik dan supernatant dibuang. Dilarutkan kembali sel dengan 0,5 $\mathrm{mL} \mathrm{Li}$ asetat dan inkubasi pada temperatur $30^{\circ} \mathrm{C}$. Dididihkan single strand DNA carrier (salmon sperm) selama 5 menit dan dengan cepat dinginkan dalam es selama 5 menit. Suspensi sel divorteks, dipipet $0,1 \mathrm{~mL}$ sampel dan dikumpulkan sel dengan sentrifugasi pada $12.000 \mathrm{rpm}$ selama 30 detik dan supernatannya dibuang. Tambahkan berturut-turut 0,24 mL PEG $4.00050 \%(\mathrm{w} / \mathrm{v}), 0,036 \mathrm{~mL}$ Li Asetat 1,0 $\mathrm{M}, 0.005 \mathrm{~mL}$ carrier DNA $(10 \mathrm{mg} / \mathrm{mL})$, dan 0,070 mL DNA hasil PCR $(0,1-10 \mu \mathrm{g})$ 
dan air steril. Vorteks hingga bercampur sempurna. Inkubasi selama 30 menit pada $30^{\circ} \mathrm{C}$, heat shock selama 20 hingga 25 menit pada $42{ }^{\circ} \mathrm{C}$. Sentrifugasi campuran pada $12.000 \mathrm{rpm}$ selama satu menit dan buang supernatan secara sempurna. Tambahkan $0,1 \mathrm{~mL}$ suspensi sel yang dilarutkan dengan $0,1 \mathrm{~mL}$ air steril. Sebarkan suspensi sel yang telah ditransformasi pada medium selektif tanpa mengandung histidin. Inkubasi pada $30^{\circ} \mathrm{C}$ selama $2-3$ hari hingga muncul koloni-koloni transforman.

\section{Elektroforesis gel agarosa terhadap fragmen DNA}

Elektroforesis gel agarosa dilakukan sesuai dengan Sambrook et al, 1989 dengan sedikit modifikasi.

Gel agarosa $1 \%$ dibuat dengan melarutkan 0,4 g agarosa dalam $40 \mathrm{~mL}$ bufer TAE 1X (Tris-asetat 0,04 M; $\mathrm{Na}_{2}$ EDTA 0,001 M (pH 8,0), dipanaskan hingga mendidih, kemudian didinginkan hingga $40-50 \quad{ }^{\circ} \mathrm{C}$, lalu dituang pada cetakan gel dan dibiarkan hingga memadat. Gel agarosa diletakkan dalam alat elektroforesis dan direndam dengan bufer TAE 1X. Sampel DNA dicampur dengan loading bufer (bromofenol biru $0,1 \%$; sukrosa $50 \%$; $\mathrm{Na}_{2}$ EDTA $0,1 \mathrm{M}$ ) dan air steril. Campuran ini dimasukan ke dalam sumur gel agarosa, lalu dielektroforesis dalam medan listrik 60 volt sampai warna biru bromofenol biru bermigrasi mendekati batas akhir gel. Gel direndam dalam larutan etidium bromida
0,5 $\mu \mathrm{g} / \mathrm{mL}$ selama 1-5 menit. Pita-pita DNA diamati dengan sinar ultra violet (UV).

\section{HASIL DAN PEMBAHASAN}

Mutan

$\Delta p t c 2: \mathrm{CgHIS3}$

dikonstruksi menggunakan strain FY833 dengan $\operatorname{can}^{\mathrm{r}}$ sebagai parental strain dilakukan dengan menggunakan metode penggantian gen target dengan $P C R$ mediated disruption (Sakumoto, et al., 1999; 2002). Strategi desain primer untuk merusak gen target seperti pada Gambar 1.

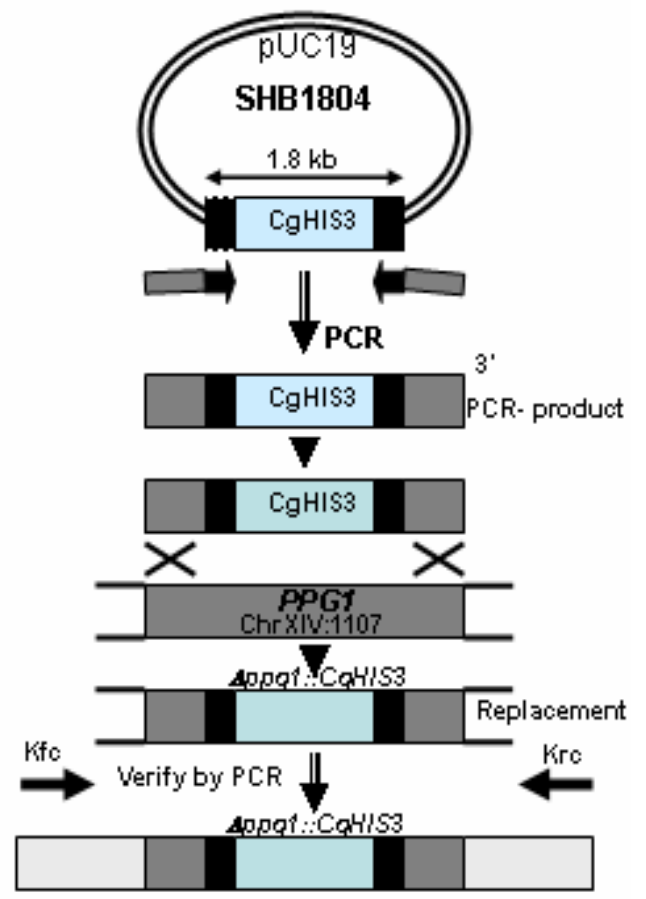

Gambar 1. Strategi penggantian gen PTC2

oleh CgHIS3

Dengan metode ini kita harapkan protein PTC2 tidak dapat melakukan aktivitasnya lagi. Masing-masing forward primer atau reverse primer terdiri atas 40 
nukleotida dari gen PTC2 dan 20 dari gen protein fosfatase PTC2 yang nukleotida dari gen $\mathrm{CgHIS3}$ yang terdapat di kromosom $\mathrm{V}$ terdiri atas 1395 terdapat pada plasmid SHB1804 yang merupakan derivat dari plasmid pUC19 nukleotida (Dietrich, et al., 1997) (Kitada et al, 1995). Urutan nukleotida berdasarkan yeast genome $S$. cerevisiae data base (Tabel 1).

Tabel 1: Urutan nukleotida dari gen $P P G 1$

1 ATGGGACAAA TTCTATCAAA CCCGGTAATT GATAAAGAGA GCCACTCCGG

51 TGCTGACTCC TTGACCGCGT TTGGACTGTG TGCAATGCAA GGGTGGCGGA

101 TGTCAATGGA GGATTCACAC ATTCTAGAGC CTAATGTTTT GACAAAGTCC

151 GATAAGGACC ATATTGCATT TTACGGTATA TTCGATGGTC ATGGTGGCGC

201 TAAAGTAGCA GAATACTGTG GTAATAAAAT AGTGGAGATC CTGCAAGAGC

251 AGAAATCGTT CCATGAAGGA AATTTACCAA GGGCTTTGAT TGATACTTTC

301 ATAAACACAG ACGTGAAACT GTTACAAGAT CCTGTGATGA AAGAAGACCA

351 TAGCGGATGT ACGGCTACAT CCATATTAGT ATCAAAGTCC CAGAACTTGT

401 TAGTATGTGG TAACGCTGGT GACAGTAGAA CCGTACTCGC CACCGACGGG

451 AACGCAAAGG CATTATCATA CGATCACAAG CCCACTCTAG CAAGCGAAAA

501 ATCACGTATT GTGGCAGCTG ATGGCTTCGT AGAAATGGAT AGGGTCAACG

551 GTAACTTGGC GCTCTCTCGT GCCATTGGTG ATTTTGAGTT

CAAATCCAAC

601 CCCAAATTGG GCCCCGAGGA GCAAATAGTG ACATGTGTTC CGGACATTCT

651 CGAGCATTCT CTAGATTACG ATAGGGACGA GTTTGTAATC TTAGCCTGTG 
701 ATGGTATCTG GGATTGTTTG ACTTCCCAAG ATTGTGTGGA CTTGGTTCAT

751 CTCGGCCTTC GCGAAGGCAA GACATTGAAT GAAATTTCTT CGCGGATCAT

801 CGATGTCTGT TGTGCTCCCA CCACAGAGGG GACGGGTATT GGATGCGACA

851 ACATGAGTAT AGTGGTTGTC GCGCTGCTGA AAGAAGGTGA AGACGTCGCT

901 CAATGGAGCG ACCGTATGAA GTCCAAGGCC CACCGCACAT CAGTGCGTTC

951 TTTTGCAGAC AAGAGAAGAA GGGTGTTTAG TTACTACGAT TTTTCCAAAT

1001 GTAACGACGA ACAGGTGTTC GCTATCACTA CGAAGAAACC TCAGGACAAA

1051 TTCACTCGCG ACCACGAAGC CGCTGTGGCC TCGGTGACTG CCGCCGATAA

1101 CGACGATCCA ATGGACATAG ACGACACGGA CGCTGACACA GATGCAGAAA

1151 ATCTTGACCC TTCCAGCCAA TCCAAGAGCA AGACCTCCGG CCCCATTGAT

1201 CTAGCATCCT TGGAGGCGCT ACTTGGTGCT ACAGGAGGAG TGAAGACAGA

1251 CAGCAACGGG AACAAAGTCA CCTACACTCT TCCCCAGTCT GCCTTGGCCC

1301 AACTGCTCCA AACCATGGGC CATGACCCGG CTTCCTCCCA TCCCGAGAAT

1351 GACAGTAACA CTGACCACAA GGCCGGCCGT TCCCACTTGC AATGA

Proses transformasi selesai setelah itu, sel-sel disebar di medium selektif plate tanpa mengandung histidin. Dua hingga tiga hari kemudian terlihat beberapa koloni-koloni tumbuh di medium selektif tanpa histidin tersebut. Hal ini mengindikasikan bahwa pada transforman terjadi penggantian gen
PTC2 oleh CgHIS3 dengan cara ntegrasi pada kromosom $S$. cerevisiae. Wild type strain FY833 yang memiliki $\operatorname{can}^{\mathrm{r}}=$

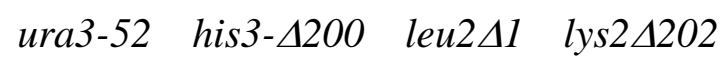
trp1 163 sebagai parental strain, karena gen pengkode histidin yang rusak (defect) membuat sel tidak bisa menghasilkan histidin sebagai fenotip auksotrop dari 
strain FY833, sehingga kita perlu menambahkan histidin pada medium. Pada koloni-koloni transforman histidin dapat diekspresi oleh gen $\mathrm{CgHIS3}$ yang menggantikan gen PTC2 pada kromosom S.cerevisiae tersebut, sehingga sel sel dapat hidup pada medium selektif tanpa histidin.

Konfirmasi lebih lanjut untuk lebih meyakinkan bahwa transforman betul-betul membawa ptc2::CgHIS3, dilakukan menggunakan $P C R$ analysis
(PCR-based confirmation). Tujuh belas koloni yang diuji DNA kromosomnya dan dianalisis dengan DNA elektroforesis gel agarosa 1\% (Gambar 2), 9 koloni menghasilkan dengan jelas pita yang berukuran $3,52 \mathrm{~kb}$ yang merupakan ukuran transforman ptc $2 \Delta::$ CgHIS3 pada lajur no. 2, 4, 5, dan 6. Lajur 7 adalah wild type PTC2 berukuran 2,9 kb $(1 \mathrm{~kb}$ upstream PTC2 + 1,4 kb PTC2 + 0,5 downstream PTC2).

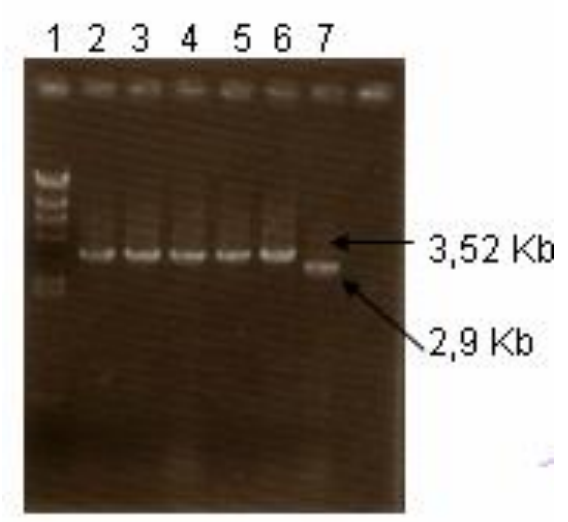

Gambar 2. Konfirmasi ukuran DNA menggunakan elektroforesis gel agarosa $1 \%$.

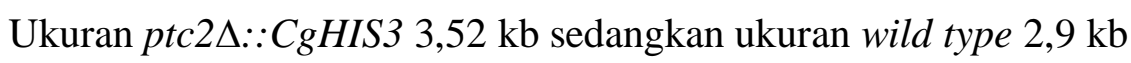

Adanya transforman yang menunjukkan hasil positif atau dapat tumbuh pada medium seleksi tanpa mengandung histidin tapi menghasilkan hasil negatif menggunakan PCR atau menghasilkan pita yang mirip dengan pita dari wild type mengindikasikan bahwa adanya kemungkinan CgHIS3nya terintegrasi dengann tidak menggantikan gen target $P T C 2$.

\section{KESIMPULAN DAN SARAN \\ Kesimpulan}

Berdasarkan hasil yang diperoleh dari penelitian ini dapat diambil kesimpulan sebagai berikut :

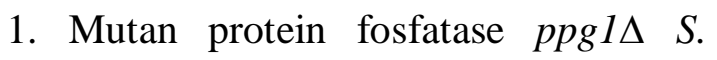
cerevisiae, dikonstruksi dengan merusak gen target PTC2 pada kromosom menggunakan medoda PCR-mediated disruption yang menggunakan auksotrop marker HIS3 yang berasal dari $C$. albicans.

2. Konfirmasi mutan ptc $2 \Delta:: \mathrm{Cg} H I S 3$ 
yang dilakukan menggunakan metoda PCR-based confirmation menghasilkan ukuran $p t c 2 \Delta:: \mathrm{Cg} H I S 3$ 3,52 Kb, sedangkan PTC2 2,9 Kb.

\section{Saran}

Perlu penelitian lebih lanjut untuk mengetahui kerusakan gen PTC2 yang menyebabkan sel kehilangan aktivitas protein $P T C 2$.

\section{UCAPAN TERIMA KASIH}

Terima kasih saya ucapkan kepada Prof. Satoshi Harashima dari Osaka University yang mendanai penelitian ini. Terima kasih juga kepada Dr. Yoshinobu Kaneko dan Dr. Minetaka Sugiyama yang telah memberikan banyak masukkan pada penelitian ini.

\section{DAFTAR PUSTAKA}

Dietrich FS, et al. 1997. The nucleotide sequence of Saccharomyces cerevisiae chromosome V. Nature 387(6632 Suppl):78-81.

Hermansyah, M. Sugiyama, Y. Kaneko, S. Harashima. 2009. Yeast protein phosphatase Ptp2p and Msg5p are involved in G1-S transition, CLN2 transcription and vacuole morphogenesis. Arch Microbiol 191:721-733.

Hirasaki, M., Y. Kaneko, S. Harashima. 2008. Protein phosphatase Siw 14 controls intracellular localization of
Gln3 in cooperation with Npr1 kinase in Saccharomyces cerevisiae. Gene 409:34-43.

Kitada, K., E. Yamaguchi, M. Arisawa. 1995. Cloning of the Candida glabrata TRP1 and HIS3 genes, and construction of their disruptant strains by sequential integrative transformation. Gene 165:203-206.

Leroy C, et al. 2003. PP2C phosphatases Ptc2 and Ptc3 are required for DNA checkpoint inactivation after a double-strand break. Mol. Cell. 11(3):827-35.

Miyakawa, T. dan M. Mizunuma. 2007. Physiological roles of calcineurin in Saccharomyces cerevisiae with special emphasis on its roles in G2/M cell-cycle regulation. Biosci Biotechnol Biochem 71:604951-6049513.

Sakumoto, N., I. Matsuoka, Y. Mukai, N. Ogawa, Y. Kaneko, S. Harashima. 2002. A series of double disruptants for protein phosphatase genes in Saccharomyces cerevisiae and their phenotypic analysis. Yeast 19:587-599.

Sakumoto, N., Y. Mukai, K. Uchida, T. Kouchi, J. Kuwajima, Y. Nakagawa, S. Sugioka, E. Yamamoto, T. Furuyama, H. Mizubuchi, N. Ohsugi, T. Sakuno, K. Kikuchi, I. 
Konstruksi Mutan Protein Fosfatase Ptc2 $\Delta$ Saccharomyces Cerevisiae... (Hermansyah)

Matsuoka, N. Ogawa, Y. Kaneko, S.

Harashima. 1999. A series of protein phosphatase gene disruptants in Saccharomyces cerevisiae. Yeast 15:1669-1679.

Sambrook, J., E.F. Fritsch, dan T. Maniatis. 1989. Molecular cloning: a laboratory manual. $2^{\text {nd }}$ ed, Cold Spring Harbor Laboratory, New York.
Sherman, F.2002. Getting started with yeast, Methods Enzymol 350:3-41.

Young C, et al.2002. Role of Ptc2 type 2C Ser/Thr phosphatase in yeast high-osmolarity glycerol pathway inactivation. Eukaryot. Cell. 1(6):1032-40. 